\title{
Public Participation in the Enforcement of the Antitrust Laws
}

\author{
Richard M. Buxbaum*
}

The United States enjoys the reputation of possessing a long and vigorous tradition of antitrust enforcement. However, the length of the tradition is in fact a matter of some doubt. Its vigor has emerged only in recent years, as the courts have supported attacks upon traditional patterns of distribution and upon existing structures of American industrial organization. With this activity has come an attendant increase in criticism: criticism of the enforcement pattern itself, and criticism of the role of antitrust laws in modern economic organization. ${ }^{1}$ At the same time, economic affairs have become a central concern of government-a concern not new in principle, but new in its intensity and in the range of means available to implement that concern. ${ }^{2}$

The present study attempts to explore specific enforcement mechanisms as they affect the implementation of current antitrust policies. Preoccupation with substantive antitrust law doctrine on the part of experts in this field now threatens neglect of what has become the more important problen of antitrust enforcement doctrine. ${ }^{3}$ The preoccupation is understandable, given the newness and completeness of the substantive doctrinal revolution we have witnessed, even though the theory and empirical economic studies justifying it are not all so recent. This Article briefly reviews the doctrimal development and its theoretical and political support in an effort to explam why we have arrived where we are. The major part of the discussion, however, focuses on the enforcement pattern that this development has engendered, the dan-

* Professor of Law, University of California, Berkeley. A.B. 1950, LL.B. 1952, Cornell University; LL.M. 1953, University of California, Berkeley.

1. See, e.g., Bork \& Bownan, The Crisis in Antitrust, 65 Colum. L. REv. 363 (1965); Dam, Fortner Enterprises v. United States Steel: "Neither a Borrower nor a Lender Be," 1969 Sup. Cr. Rev. 1; Kauper, The "Warren Court" and the Antitrust Laws, 67 Mich. L. REv. 325 (1968).

2. See generally Buxbaum, Antitrust Policy in Modern Society, in Das UNTERNEHMEN IN DER RECHTSORDNUNG 345 (1967); Cook, Merger Law and Big Business, 40 N.Y.U.L. REv. 710 (1965); Sullivan, Politics, Planning and Trade Regulation, 16 U.C.L.A.I. REV. 1 (1968).

3. See Buxbaum, Book Review, 68 Colum. L. Rev. 1618 (1968); Dam, supra note 1 , at 40 . 
gers and inadequacies of that pattern, and possible improvements in antitrust enforcement policy.

\section{Social Values and Antitrust Policy}

No exploration of the forces of substantive law and enforcement can have form or focus without at least some tentative value judgnents guiding the evaluation of success or failure in the enforcement of any given antitrust policy. In general, and with the reservation noted below, I subscribe to the scliool of opinion expressed in the following quotation from Kaysen and Turner:

The most important aspect of the competitive process is that it is self-controlling with regard to private economic power. For all the important qualifications and limitations of the doctrine of the invisible hand which modern economic analysis has produced, that doctrine remains the basic political justification for an cnterprise economy in which major economic decisions are compelled and coordinated through the market. It is the fact that the competitive process compels the results of its processes which is the ultimatc defense against the demand that economic decisions be made or supervised by politically responsible authorities. Without such market compulsion, that demand appears irresistible in a society committed to representative government. ${ }^{4}$

My reservation to this statement concerns the conflict between certain goals of today's society and certain assumptions and expectations postulated by the classical theory of competition that informs the quoted passage. ${ }^{5}$ Put crudely, the classical process achieves its utilitarian aims-maximum utilization of scarce resources to produce the most products at the least cost - by means of an ongoing cyclical pattern around the never-achievable ideal of optimal resource allocation. This pattern may bring with it unemployment and bankruptcies on firm and even industrywide scales as it moves over time about the liypothetical optimal position. Today, however, unemployment and large-scale bankruptcies are evils; they are stated to be such by legislative commands expressing certain values, legitinate by definition, of democratic society. The clearest example is the "magic quadrangle": the stated desire for full employment in a stable and noninflationary system, with a constant expansion of the real standard of living. The classical theory expects these goals to be achieved, but allows shortrun defeats on the way to their realization. It is just these shortrun de-

4. C. KAYSEN \& D. TURNER, ANTITRUst Policy 48-49 (1965) (footnote omitted). See also J. Dirlam \& A. KaHn, Fatr Competition: The LAW and Economics of ANTTTRUST Policy 16-18 (1954).

5. The following vulgarization borrows from Buxbaum, Antitrust Policy, in LAW and Institutions In the Atlantic ARea 517 (E. Stein \& P. Hay eds. 1967). 
feats, however, that are no longer acceptable as a matter of governmental policy, and more to the point, that are fought by today's administrative bureaucracies, in great part because of the pressures of popular-party and interest-group government.

These shortrun defeats are fought by an ever-expanding arsenal of devices, mcluding the informal, "back stairs" manipulative and persuasive methods made notorious by their use in the steel-price fights of some years ago. ${ }^{6}$ More relevant to our discussion, these so-called evils can be fought, though at unknown cost, by relaxing the vigorous application of antitrust law. Since the combat against these evils is by definition legitimate, hesitancy to go the whole distance on antitrust law enforcement may indeed be proper. The problem is one of striking the proper balance: a decision not to enforce antitrust principles is never free of cost; the sane is true of any decision deprecating the primacy of the above-mentioned "overriding" values."

This clash of values creates a secondary, but no less difficult problem. While the enforcement of the antitrust laws is seen in the context of discrete legal decisions, the issues in controversy imvolve disagreement over vaguely stated matters of policy. The single enforcement decisions should not be arbitrary or inordinately unpredictable; the prosecutorial discretion concerning the filing of a complaint-wliether civil or criminal-cannot go so far as to mock the substantive rules that are supposed to be enforced. ${ }^{8}$ On the other hand, the substantive standards must be broad enough both adequately to cover the entire range of undesirable practices and structural situations, and adequately to subsume the legitimate sliortrun considerations already described. As a result a dilemma is apparent in the enforcement picture. The breadth of the substantive law required for adequate control of potential structural and behavioral aberrations creates the danger of either a politically impossible and irresponsibly rigorous level of enforcement, or a dangerous amount of freedoin in a field far removed from those traditionally subject to accepted standards of prosecutorial discretion. Such wide discretion, even if politically responsible and apolitically fair, is still unpredictable and arbitrary from the point of view of industry. In addition, given the prevalent erosion of the presumption that politically derived power is exercised more responsibly than economically derived

6. See generally G. McConneld, Steel and the Presidency, 1962 (1963).

7. See Sullivan, supra note 2, at 34-35.

8. See, e.g., An Interview with the Honorable Donald F. Turner, Assistant Attorney General in Charge of the Antitrust Division, 34 ANTITRUST L.J. 113, 125-27 (1967); Zimmerman, Views from the Antitrust Division, 37 ANTrTRusT L.J. 815, 816 (1968). See also Buxbaum, supra note 2, at $362 \&$ n.70; N.Y. Times, May 9, 1965, at 36, col. 1. For a specific case example of the problem, see N.Y. Times, Nov. 26, 1970, at 1 , col. 7, and in connection therewith, In re Warner-Lambert Co., 3 TRADE REG. REP. II 19,592 (Apr. 20, 1971). 
power, such discretion raises serious questions of public accountability. ${ }^{0}$

The current state of substantive antitrust law in this country shows that the judiciary has cliosen the second horn of the dilemma and accepted the risk of arbitrary enforcement practices. In the fields that count-restrictive distribution practices ${ }^{10}$ and mergers ${ }^{11}$ - the Supreme Court lias opted for carte blanclie to the enforcement agencies. As a result we face the problem that legitimate policies antithetical to economic-efficiency values must be assimilated as imputs to the agencies' enforcement decisions rather than faced as countervailing doctrinal challenges in the judicial development of substantive antitrust rules. ${ }^{12}$ Thus, paradoxically, success in establishing the broadest possible substantive antitrust doctrine has sown the seeds for failure in its application. ${ }^{13}$ This paradox can only be resolved if we accept more significant private and judicial participation in these administrative processes, whether the agency is such in legal parlance, as in the case of the Federal Trade Commission, or seems at first glance to be a prosecuting office only, as in the case of the Antitrust Division of the Department of Justice. $^{14}$ This may entail rethinking the justification of traditional administrative-law standards (which in fact developed exigently to safeguard the execution of New Deal legislative policies ${ }^{16}$ ), but is necessary if we are to preserve the automatic and impersonal nature of market forces, cherished by Kaysen and Turner, ${ }^{10}$ in a situation in which the executive has the right as well as the power to overrule those forces.

This Article discusses primarily one aspect of this situation: the possibility of interested third-party public involvement im the governmental decisional process which initiates or terminates antitrust enforcement proceedings. Other aspects of the overall antitrust enforcement picture are only imcidentally brought into the discussion. Thus, the discussion considers intervention but is not intended as a legal analysis of the state of Rule $24 .{ }^{17}$ Similarly, consent decree settlements are discussed, but the Article does not present an analysis of problems concerning consent decrees as such; rather, it presents solely views about the interplay of public and private forces in reaching decisions to enforce the antitrust laws.

9. See generally Elman, Administrative Reform of the Federal Trade Commission, 59 GEO. I.J. 777 (1971).

10. See, e.g., FTC v. Brown Shoe Co., 384 U.S. 316 (1966).

11. See, e.g., Brown Shoe Co. v. United States, 370 U.S. 294 (1962).

12. See Dam, supra note 1, at 2; Kauper, supra note 1, at 335; cf. Posner, $A$ Program for the Antitrust Division, 38 U. CH. L. REv. 500 (1971).

13. See Buxbaum, supra note 2, at 352.

14. See Elman, supra note 9. But see L. JAFFe, Judicial Control of ADMINISTRATIVE ACTION 60-72 (1965).

15. See generally $1 \mathrm{~K}$. Davis, Administrative LAW Treatise 27-30 (1958).

16. See note 6 supra and accompanying text.

17. FED. R. Civ. P. 24. 
II

\section{Participation in the Agency Process}

Third-party participation in adjudicatory proceedings before courts or agencies is normally taken as a single, irreducible thing, and accepted or rejected by reference to the magic concept of "standing." In the regulated sectors of the economy we have tended to examine the organic acts governing each sector, presumed that they define the decision-participation routine in the governmental processes relating to that sector, and concluded that in this or that industry competitors, customers, suppliers, or other more vaguely ascertainable affected groups do or do not enjoy this unitary right of participation. ${ }^{18}$ Where the right is denied, the suppliants have been deemed caught in the internal-affairs trap of Perkins v. Lukens Steel Co. ${ }^{19}$ or told that competition as such is not protectable and therefore yields no standing. ${ }^{20}$

However, at both the agency and judicial levels of activity, it has become increasingly apparent that this is, if not a fight on false fronts, ${ }^{21}$ at least a fight not so easily disposed of. Quite apart froin the taxpayer doctrine, ${ }^{22}$ a growing list of expansions of the judicial standing concept testifies to increasing dissatisfaction with the traditional notions. ${ }^{23}$ At the agency level, too, a revival of participation rights is evident; it is beginning to generalize from the fragmented, sector-by-sector rules with which we have lived during the past several decades. The recent efforts of the Federal Trade Commission to improve public participation offer strong confirmation of this growing view that there slould be a right to intervene in the appropriate elements of the agency's business. Dissenting froin the Commission's timid concession of limited participation rights to interested parties when voluntarily subımitted merger-clearance requests are being decided, ${ }^{24}$ then-Commissioner Elman stated:

The filing of an application with the Federal Trade Commission for approval of a merger is a matter of substantial public interest. Knowledge of the filing of such an application should not be restricted to 'imsiders', [sic] either in the companies involved or the Commission. Why should an application for merger approval be treated differently from, say, an application to the FCC for a television station license,

18. See generally $3 \mathrm{~K}$. DAvis, supra note 15 , at 208-94; L. JAFFe, supra note 14 , at $501-45$.

19. 310 U.S. 113, 126 (1940).

20. E.g., Tennessee Power Co. v. TVA, 306 U.S. 118, 137-39 (1939).

21. See, e.g., Lewis, Constitutional Rights and the Misuse of "Standing," 14 Stan. L. Rev. 433 (1962).

22. See Flast v. Cohen, 392 U.S. 83 (1968).

23. See Association of Data Processing Serv. Organizations v. Camp, 397 U.S. 150 (1970); Barlow v. Collins, 397 U.S. 159 (1970); Arnold Tours, Inc. v. Camp, 397 U.S. 315 (1970).

24. FTC Press Release (May 23, 1969); see 3 Trade Reg. Rep. Tl 9738 (1969). 
or to the ICC for approval of a railroad merger, or to the CAB for certification of an air route? The essential point is that all of such applications are very mucli the public's business, and not merely the concern of the applicant and the particular government agency. ${ }^{25}$

Important to the continued strength of this trend is a flexible approach to the details of the participation process to which an interested party should be entitled of right rather than, as the Commission would havc it, of grace. In iny opinion, a bundle of appropriate participation privileges must be shaped to the specific substantive and procedural parameters within which each governmental authority exercises its delegated functions. That the concept of participation should be derived from and vary with the functions performed by each governmental authority is not so unique as might be supposed from the influence that the unitary concept has enjoyed in the no-standing cases. An analogy is provided by the right-to-counsel cases; where courts have considered in detail the right to counsel provided by section 6(a) of the Administrative Procedure Act, ${ }^{26}$ they have shaped the role of that counsel to the specific agency involved. ${ }^{27}$

Section 5(b) of the Administrative Procedure Act, ${ }^{28}$ while by its terms only applicable when specific statutes so provide, suggests a type of participation in the adjudicatory functions of an agency which can serve as a general paradign for granting appropriate participation privileges, geared to the exigencies of each agency's functions. Section 5(b) states that an agency

shall give all interested parties opportunity (1) for the submission and consideration of facts, arguments, offers of settlement, or proposals of adjustment when time, the nature of the procecding, and the public interest permit . . . . ${ }^{29}$

If we begin with such a concept, the reasonable application of which seems definable, we can safely and in a political sense responsibly urge upon the courts the double duty of extending soine participation by

25. FTC Press Release (May 23, 1969), Separate Statement of Commissioner Elman 2. See also Elman, supra note 9; In re Firestone Tire \& Rubber Co., 3 TRAde Reo. REP. If 19,373 (Oct. 26, 1970) (allowing intervention to a student consumer-interest organization). Compare this with the earlier, cautious approach of the Commission to participation of public-interest volunteers in the relief pliase of a consent order proceeding; In re Campbell Soup Co., [1967-1970 Transfer Binder] TRADE Reo. ReP. If 19,261 (1970).

26. 5 U.S.C. \& $555(\mathrm{a}) \&(\mathrm{~b})(1970)$.

27. See FCC v. Schreiber, 329 F.2d 517, 524-26 (9th Cir. 1964), modified on other grounds, 381 U.S. 279 (1965) (discussing nonadjudicative investigative hearings); cf. City of San Antonio v. CAB, 374 F.2d 326, 331-33 (D.C. Cir. 1967). There are constitutional limitations on restricting participation rights. See Jenkins v. McKeithen, 395 U.S. 411 (1969).

28. 5 U.S.C. $\$ 554(c)(1970)$. But see Teamsters Local 282 v. NLRB, 339 F.2d 795 (2d Cir. 1964).

29. 5 U.S.C. $\$ 554(c)(1970)$. 
third parties to most dispositive processes of government, while judiciously shaping the degree of that participation to the particular governmental function. Subject to due process limitations, one is tempted to say; yet the concept of due process itself, as applied to various types of agency proceedings and in situations at various removes from the plain taking of property, is the best possible confirmation of this relative, functional standard. In particular, this section 5(c) paradigm provides a sound conceptual framework for defining third-party participation in governmental decisions-whether by the Federal Trade Commission or the Justice Department-about antitrust enforcement. The notion that not only the Federal Trade Commission but the Department of Justice is an administrative agency is growing of acceptance when considered in the transactional context, ${ }^{30}$ in that same context the applicability of the principles underlying APA section $5(\mathrm{~b})$ to the Department ought to be equally acceptable, given the limitation of the statute to conduct sufficiently ordered to be called a "function," and the limitation of "participation," as stated, to the compatible elements of the Department's functions. ${ }^{31}$

Assuming, then, the propriety of some public participation in antitrust enforcement, I propose to examine in detail the roles played by each of the antitrust agencies to determine precisely what participation is appropriate. The discussion is directed along four axes: the substantive antitrust transaction or doctrine involved; the way in whicl the agency's consideration of an enforcement matter was initiated; the decision of the agency to proceed agaimst the transaction, and especially the relationship of that decision to subsequent judicial consideration of it; and the reason for the third party's participation. In this discussion I do not distinguish between the functions of the Antitrust Division of the Department of Justice and those of the Federal Trade Commission, because I believe that in most cases they should be treated the same. Since the role of the Department is most difficult to fit into an "agency" context, most of the discussion is centered upon it. Only where the FTC's processes specifically differ are they considered separately; otherwise they are deemed subsumed within the discussion of the Department's processes.

\section{A. Proceedings Before the Agencies}

At the outset it is necessary to draw some distimctions, because different participation rights are appropriate in different situations. First,

30. See generally Buxbaum, supra note 2, at 361; Dam, supra note 1, at 2; Posner, supra note 12; Sullivan, supra note 2.

31. See Newman, What Agencies Are Exempt from the Administrative Procedure Act?, 36 Notre Dame L. Rev. 320 (1961). 
we shall distinguish two types of prospective intervenors in the agency process leading to a decision whether or not to enforce the antitrust laws against a specific transaction or situation. ${ }^{32}$ The first seeks to obtain a specific remedial result, such as the inaintenance of a continuing and competitive supply of natural gas; ${ }^{33}$ the second seeks to prevent the entry of a consent decree, or at least to assure that any consent decree contains an "asphalt clause," a provision that the defendant waives the protection otherwise automatically granted by a consent decree against the use of the consent judgment as prima facie evidence of an antitrust violation in later private actions. ${ }^{34}$ Second, we distinguish between enforcement proceedings initiated as a result of the receipt of a specific complaint from a private party and those initiated as a result of the receipt of general information, such as press reports or the report of a congressional investigation.

\section{Specific Complaints}

A decision by the Department of Justice not to proceed after the receipt of a specific private complaint ought to be open to scrutiny in two senses. First, before a decision not to proceed is made, the originally complaining party ought to be given a forum for an ex parte presentation of its argument or, at the least, an opportunity to submit additional documentation in support of its original complaint, because the complaint itself, by definition, was imadequate to motivate departmental action. Second, decisions not to proceed ought to be publicized and accompanied by a statement of the Department's reasons for not acting. ${ }^{35}$ The customary explanation that action would not be in the pub-

32. For a discussion of the range of the concept of intervention, see Shapiro, Some Thoughts on Intervention Before Courts, Agencies and Arbitrators, 81 HARv. L. Rev. 721 (1968).

33. See, e.g., Cascade Natural Gas Corp. v. El Paso Natural Gas Co., 386 U.S. 129 (1967).

34. Clayton Act $\$ 5(a), 15$ U.S.C. $\$ 16(a)$ (1964); see, e.g., United States v. Harper \& Row Publishers, Inc., 1968 Trade Cas. $\pi$ 72,423 (N.D. Ill. 1967), aff'd mem. sub nom. City of New York v. United States, 390 U.S. 715 (1968). For a review of consent decree practice see M. Goldberg, The Consent Decree: ITs Formulation and Use (1962); Flynn, Consent Decrees in Antitrust Enforcement, 53 Iowa L. Rev. 983 (1968). For a dicsussion of the effort to avoid the application of the proviso of Clayton Act $\S 5$ (a), 15 U.S.C. $\S 16$ (a) (1964) to bar the prima facie effect of the judgment in subsequent private litigation through the waiver of the proviso by respondents (the "asphalt clause"), see McHenry, The Asphalt Clause-A Trap for the Unwary, 36 N.Y.U.I. Rev. 1114 (1961). The effort was never very successful and has now been abandoned. However, the government seems to have the power to inake inclusion a condition of its agreement to the entry of a consent decree, even if no disagreement about substantive relief remains between the original parties. See United States v. Ward Baking Co., 376 U.S. 327 (1964).

35. See Note, 57 VA. L. Rev. 331, 338 (1971); Note, Informal Bargaining Process: An Analysis of the SEC's Regulation of the New York Stock Exchange, 80 YALE L.J. 811, 832 (1971). 
lic interest is meaningful only in an economic or legal context; ${ }^{36}$ either the complaint airs a private quarrel and the challenged practice is not prevalent in an economically significant trade or number of situations, or the practice does not violate the laws as the Department understands them. A decision refusing to proceed should specify which of these objections is applicable and why. Little increase in work load would be involved, for such specification states only the minimum of information that the decisionmaker had to lave in order legitimately to arrive at a decision in the first place. ${ }^{37}$

These suggestions imply that a refusal to prosecute might be judicially reviewed as an abuse of discretion. ${ }^{38}$ There are few cases actually mandating a prosecutor to prosecute a criminal case; ${ }^{39}$ however, the general model of prosecutorial discretion is not really appropriate. While neither the criminal prosecutor nor the antitrust-agency civil prosecutor sliould be burdened with bagatelles, a lower threshold level for review is appropriate in the antitrust realm. Two distinctions are apparent and appealing. First, only in the antitrust field might one expect frequent significant disputes about the applicable law, and there is no apparent reason why in a case of clear error a private complainant should not be able to force the Department's lrand. ${ }^{40}$ A good example is the long delay of the Departinent of Justice in moving against consignment practices in the oil-distribution field, with the result that a plaintiff in a private suit eventually had to move the Supreme Court to

36. I recognize that this is one of the statutory standards that must be met before FTC action is proper. Federal Trade Commission Act $\$ 5(\mathrm{~b}), 15$ U.S.C. $\S 45$ (b) (1964). Nevertheless-and even assuming the applicability of this criterion to the Department of Justice-this is a conclusion that should be stated only with accompanying argument; it is not an explanation in itself.

37. See Saferstein, Nonreviewability: A Functional Analysis of "Committed to Agency Discretion," 82 HARv. L. REv. 367, 387 n.86 (1968).

38. But see Elman, supra note 9, at 786; Rotunda, The Public Interest Appellant: Limitations on the Right of Competent Parties to Settle Litigation out of Court, 66 Nw. U.L. Rev. 199, 202 (1971). Both authors, although equally critical of present practices, assert the traditional view of nonreviewbility of "prosecutorial discretion." To the extent, however, that they rely upon FTC v. Universal Rundle Corp., 387 U.S. 244 (1967), for specific support of this position, I am not persuaded. It seems that a decision concerned with the impact upon a respondent of selective enforcennent that leaves its competitors free for a time of the constraint it has suffered may properly set both higher and shightly different standards of abuse as conditions of reviewability than those properly applicable to abuses involving inaction.

39. See generally K. DaVis, DiscretionaRY Justice 207-14, 225-26 (1969); Davis, A New Approach to Delegation, 36 U. CHI. L. Rev. 713, 724 n.33 (1969). Both present a pessimistic appraisal. For a discussion of the more differentiated approach of other legal systems, see W. Weidinger, Der Rechtsschutz BetroffenNer DritTer Im KartellVERWALTUNGSRECHT DER EUROPÄISCheN WIRTSCHAFTSGEMEINSCHAFTEN (1968).

40. This would be a particularly important corrective were the Department avowedly to pursue selective prosecution on doctrinal grounds. See Posner, supra note 12 . 
extend old doctrines to this new field. ${ }^{41}$ A second distinction lies in the differing concept of administrative flexibility involved in ordinary criminal prosecution and in antitrust actions. Criminal prosecution is exceedingly decentralized and decisions to bring or abstain froin an action are highly factual and evidentiary in nature; as a result, a highly variegated pattern of prosecution develops, whose geographical component parts are able to influence each other reciprocally over time. Antitrust actions, on the other hand, are highly centralized, relatively few in number, and relatively large in individual impact; as a result, enforceinent patterns can be sharply and significantly distorted without an opportunity for ongoing reactive or corrective action by other-minded actors. Therefore, even though prosecutorial enforcement decisions fall toward the "nonreviewable" end of the spectrum, ${ }^{42}$ the particular nature of the discretion exercised by the antitrust agencies indicates that here courts should retain the ability to review abuses that are factually gross or doctrinally erroneous. ${ }^{43}$ While recent cases such as Medical Commission for Human Rights v. SEC $C^{44}$ and Environmental Defense Fund, inc. v. Hardin, ${ }^{45}$ involving complaints against the inaction of agencies, may not be entirely apropos, ${ }^{48}$ their refreshing willingness to

41. Simpson v. Union Oil Co., 377 U.S. 13 (1964); see Simpson v. Union Oil Co., 396 U.S. 13 (1969). For another example of third-party input creating new substantive law, compare In re Cambell Soup Co., 3 TRADE REG. REP. If 19,261 (1970) with In re ITT Continental Baking Co., 3 TRADE REG. REP. If 19,681 (July 2, 1971).

42. See generally Saferstein, supra note 37. Since I am interested in extending review of discretion to an untraditional field, I hope to be excused from participation in the Berger-Davis debate over the significance of APA $\S 10$, Intro., sub. (2), 5 U.S.C. $\$ 701$ (a) (1971). See sources cited in Berger, Administrative Arbitrariness, 78 YALE L.J. 965, 966 n.9 (1969). See also Independent Broker-Dealers' Trade Ass'n v. SEC, 442 F.2d 132, 137 (D.C. Cir. 1971).

43. The very obhigation to resort publicly to resource-allocation arguments as justification for particular inaction should have a salutary chilling cffect upon abuse of this argument-and sparingly used may not be an inappropriate input to the budgetary process.

44. 432 F.2d 659 (D.C. Cir. 1970), cert. granted, 401 U.S. 973 (1971).

45. 428 F.2d 1093 (D.C. Cir. 1970). See also Moss v. CAB, 430 F.2d 891 (D.C. Cir. 1970) (refusal of CAB to suspend proposed rates); Curran v. Laird, 420 F.2d 122 (D.C. Cir. 1969) (union conplaint against failure of Executive to enforce Cargo Preference Act, 10 U.S.C. $\$ 2631$ (1964)); Safir v. Gibson, 417 F.2d 972 (2d Cir. 1969) (failure of FMC to act to recover subsidies allegedly illegally paid plaintiff's competitors under section 810 of the Merchant Marine Act of 1936, 46 U.S.C. $\$$ 1227 (1964)). But see People v. Bunge Corp., 25 N.Y.2d 91, 302 N.Y.S.2d 785, 250 N.E.2d 204 (1969) (expressing the more traditional view of prosecutorial discretion in an agency context).

46. Indeed, the Medical Committee case pays lip service to prosecutorial discretion. As one coinmentator put it:

Recognizing that it could not compel the Commission to exercise its discretionary power in any particular way, ... [ [the court] left the Commission free ... to refuse to take any action if manpower or other considerations of resource allocation prompted such a deeision.

Note, 57 VA. L. Rev. 331, 342 (1968); see Note, 49 Texas L. Rev. 322, 327 (1971). 
ignore the prosecutorial-discretion shibboleth and to join issue instead on such items as standing, reviewability of discretionary actions, and ripeness can well be applied in cases testing the reviewability of Department of Justice inactivity in the antitrust enforcement field.

This type of judicial review of the rejection of specific complaints involves no risk of runaway hitigation, because the level of proof required successfully to appeal from the Department's refusal to proceed would be at least as high as that required to succeed in a direct private action under section 4 of the Clayton Act. ${ }^{47}$ It is of course true that the mere allegation of an actionable abuse of discretion can always create a significant problem of delay and a diversion of the agency's energy: ${ }^{48}$ that, however, has always been an overkill argument, and it can be met here, as in other problem areas of agency discretion, by insisting upon high threshold levels of allegation and disposing of dubious cases through appropriate summary techniques, and by evaluating the transactional and imstitutional context of the specific activity against which the complaint is directed. ${ }^{49}$ Through these means it should be feasible im time to assure that neither the complainant interested in a specific corrective act nor the one simply seeking the benefits of prior governinental action for his own later private suit gains by frivolous use of this appeal channel.

\section{Nonspecific Complaints}

In the second type of agency action that proceeds without the spur of private complaint, the different factual setting requires a different concept of the role of private intervention. Further, in this situation a differentiation based upon the nature of the practice or condition involved is important. The two most important such events will undoubtedly continue to be mergers and distribution practices. Though in both cases a specific complaint is lacking as a reference point for private reaction to the governmental decision not to proceed, the appropriate substitute reference point needed to provide a participation springboard differs for mergers and for distribution practices.

See also Leighton v. SEC, 221 F.2d 91 (D.C. Cir.), cert. denied, 350 U.S. 825 (1955). But even this much requires au explanation by the agency to the court and subjects that explanation to some level of approval. See generally Citizens to Preserve Overton Park, Inc. v. Volpe, 401 U.S. 402 (1971); Saferstein, supra note 37, at 382, 395.

47. 15 U.S.C. $\$ 16$ (1964). In other words, an appellant would have to show a clear prima facie case of a violation of an antitrust norm, in addition to the appropriate level of abuse of discretion. Only the impact of the violatiou upon that appellant, a necessary component of an alternative private claim, would not be, at least theoretically, a component of his appeal from admistrative maction.

48. See Hahn v. Gottlieb, 430 F.2d 1243, 1248 (1st Cir. 1970). See generally Saferstein, supra note 37 , at 387-88.

49. See generally Saferstein, supra note 37 , at 395 . 
a. Mergers. Many mergers now fall within the FTC premerger scheme. ${ }^{50}$ This procedure requires notification to the Commission within 10 days of preliminary agreement to merge and, if applicable, no less than 60 days before consummation, of essentially any asset or stock fusion in a nonregulated sector of corporations with combined total assets of more than $\$ 250$ million. The notification is a public document, although the detailed special report (requiring submission under the four-digit SIC code of branch and plant information and under the seven-digit Census product code of product sales information) is confidential and available only to other governmental agencies, specifically including the Department of Justice. The notification, of course, implies no burden on the FTC to proceed against the particular merger, ${ }^{51}$ but it might provide the means for a private party to query, and then, using the procedure outlined above, to challenge, the decision of either

50. See FTC Resolution, FTC Press Release (Apr. 13, 1969) (FTC Order of Apr. 8, 1969); FTC Letter of Explanation, FTC Press Release (July 16, 1969); FTC Resolution, 34 Fed. Reg. 7592 (1969), as corrected, 34 Fed. Reg. 7737 (1969). See generally O'Brien, The Federal Trade Commission's Pre-Merger Notification Requirements, 14 ANTITRUST BuLL. 557 (1970) (primarily discussing the FTC's authority to require such notificatiou); Reilly, Merger Notification Program of the Federal Trade Commission, 38 ANTITRUST I.J. 679 (1969).

51. Compare the food and cement guidelines: FTC, Enforcement Policy with Respect to Mergers in the Food Distribution Industries (Jan. 3, 1967), 1 Trade REG. REP. If 4520, at 6806 (1970); FTC, Enforcemeut Policy with Respect to Vertical Mergers in the Cement Industry, 1 Trade REg. REP. If 4510, at 6801 (1967). See also FTC, Enforcement Policy with Respect to Product Extension Mergers in Grocery Products Manufacturing, 1 Trade Reg. ReP. If 4530, at 6808 (1968); FTC, Enforcement Policy with Respect to Mergers in the Textile Mills Products Industry, 1 Trade Reg. ReP. If 4540, at 6814 (1968). For an analysis of the utility of these guidelines see Note, 5 Colum. J. LAW \& Soc. Prob. 137 (Aug. 1969).

Iike the premerger notification announcements, these guidelines also use absolute monetary standards as the primary factor distinguishing presumptively good from presumptively bad mergers. This precedent plus the explicit promise to proceed against mergers in the top financial category indicate that the FTC will in the future allocate its enforcement resources to this top group of mergers. What is worrysome about this is the implication that smaller mergers generally will not be pursued sua spontc. I beheve this to be a poor guidelime in the horizontal merger field and, to some degree, in the vertical merger field. Not only are such standards unjustifiable under substantive antimerger law doctrine, but they overlook the danger residing in the hundreds of specialty-market situations which fall below the $\$ 250$ million-in-assets tcst. These miches and crannies of highly industrialized capitalism do not deserve this de facto immunity. Compare the Merger Guidelines of the Department of Justice, 1 TRADE REG. REP. If 4430, at 6681-89 (1968), which employ relative market-share determinants. They are, of course, far too general and innocent of relevant marketdefinitioual criteria to be predictively useful [see Committee Meetings, 37 ANTrTrust I.J. 876, 879, 892 (1969) (comments of Prof. Areeda)], but at least they avoid the defect of absolute size standards.

The examples of others couutries are instructive. The British act, its Australian and Canadian progeny, and the German law all provide for premerger notification requirements and utilize perceutage-of-relevant-market criteria in their guidelines. See generally III OECD, MARKET POWER AND THE LAW (1970). Such a formula, of course, is more vague and difficult to comply with than an absolute figure, but if the FTC can 
the FTC or the Department of Justice ${ }^{52}$ not to proceed against the merger.

It might at first glance seem desirable to impose an obligation to publicize a reasoned decision to let a merger event go unchallenged upon at least the FTC and, if its internal consideration of a merger for possible action should prove to be dispositive-and discoverable-upon the Department of Justice as well. ${ }^{53}$ From the point of view of potentially interested third parties, however, this goes farther than is necessary; it would suffice to impose that duty only when a question about the agency's intentions is raised by such a party. Additionally, to go farther might introduce by a back door the frequently discussed railroad release, or premerger clearance. ${ }^{54}$ These clearances are highly touted by the business community as a path to certainty in this vague field of the law; it is, however, a path that is only really favored when the agency is thought to be moving in the right substantive direction. ${ }^{55}$ At other times there is less use of premerger clearance procedures than might be expected from the way they are occasionally hailed. ${ }^{56}$ Conversely, the enforcement agencies fear the clearances, because there is

make reference to SIC and Census codes in the premerger notification form, it could with little more work devise reasonably ascertainable structural market-occupancy standards.

52. It must be assumed that the notification procedure will not affect the normal rules of operation, which permit the first to question the merger to bring the suit. See Posner, The Federal Trade Commission, 37 U. CHr. L. Rev. 47, 51-52, 54 \& n.26 (1969); Reycraft, Dealing with Enforcement Agencies Prior to Filing of Suit, 39 ANTTTRUST L.J. 174, 175 (1970); Panel Discussion, 39 ANTITRust L.J. 211-12 (1970). The mechanics of that traditional accommodation may have to be amended slightly, but that is a minor problem-and indeed, the specific reference to the Department of Justice as an agency entitled to the Special Report filings suggests that the jurisdictional issue has been resolved by the Department and the Commission. See id. at 161 (comment of Commissioner Elinan). Unfortunately, I am advised, the Department does not request the reports as a matter of practice, and thus still fails to obtain the benefits of this source of information.

53. The FTC system now provides that all dispositions of voluntary premerger clearance submissions together with a statement of reasons, but without party identification, will be made public. FTC Press Release (Aug. 6, 1969) (detailing the system first announced in FTC Press Release (May 23, 1969)); see 3 TRADE REG. REP. II 9738 (1969). This voluntary submission prograin was intended primarily for those companies subject to FTC clearance for further acquisitions under outstanding FTC orders. See Wall St. J., May 26, 1969, at 5, col. 1 (Pac. ed.). It does not apply to the premerger notification procedures discussed in note 50 supra and accompanying text.

See also SEC Securities Exchange Act Release No. 5098, [Current Transfer Binder] CCH FED. SEC. L. REP. I 77,921 (1970) (discussing the new SEC policy of publishing interpretative opinions and no-action letters).

54. See note 53 supra.

55. See Buxbaum, Restrictions Inherent in the Patent Monopoly, 113 U. PA. L. Rev. 633, 667 (1965).

56. See Reycraft, supra note 52, at 175-76; Committee Meetings, 37 ANTITRUST L.J. 886 (1968) (comment of Mr. Reycraft). 
no adversary procedure for the fact-finding and contextual placement that is so essential to decisions in this field. All im all, after considering both the American and European experience with this approach, I am of the opinion that a clearance system is oversold as to its efficacy, and that frequent use of a clearance system is unacceptably risky to the long-range enforcement process.

Furthermore, it seems to me that the legitimate imterests of the merging firms do not require a duty on the part of the enforcement agency to state a no-challenge result, for the new notification requirement imposes no duty upon the enterprises concerned to abstain from proceeding with a planned fusion. ${ }^{57}$ If, under the new notification system, notifying companies do labor under a cloud of potential legal reaction more specific and menacing than that previously facing the large company engaged in a merger transaction, then, it might be argued, it is reasonable to require that cloud to be dispelled as expeditiously as possible by the agency that created it. In fact, however, this requirement of agency action already exists; the notifying companies can force the agency to act by the simple step of beginning to proceed with the plan. True, they may be challenged, but that problem predates, and is imdependent of, the notification requirement. The preliminary mjunction device, already available to both enforcement bodies as a means to challenge mergers, can be used no earlier in the chronology of the merger scenario now than it was before the notification requirement was promulgated. It may be argued that the present situation is different because the prelimmary injunction weapon is strengthened to a significant degree by the special-report information. But the Department of Justice, through the combination of Civil Investigative Demands and preliminary ijunctions, had already achieved the same potency, ${ }^{68}$ and the FTC has achieved a sinilar potency, although in a slightly more fragmented form, through its victory in FTC v. Dean Foods $C 0 .{ }^{50}$

57. The appropriate substantive doctrinal framework for this procedure is still unclear. See Archer, Techniques of Litigating Government Merger Cases, 39 ANTTRUST L.J. 184, 191-93 (1969); Panel Discussion, 39 ANTTTRUST L.J. 211 (1969).

58. Antitrust Civil Process Act, 15 U.S.C. $\$ \S 1311-14$ (1964). But see United States v. Union Oil Co., 343 F.2d 29 (9th Cir. 1965).

For a recent box score of the Department's preliminary-injunction efforts, see United States v. Northwest Indus., Inc., 301 F. Supp. 1066 (N.D. III. 1969), and more recently, United States v. White Consol. Indus., Inc., 5 TRADE REg. REP. II 73,487 (N.D. Ohio Feb. 24, 1971). See Allis-Chalmers Mfg. Co. v. White Consol. Indus., Inc., 414 F.2d 506 (3d Cir. 1969), cert. denied, 396 U.S. 1009 (1970), for a discussion of private parties' efforts to procure preliminary injunetive relief. See also Archer, supra note 57 , at 191-93.

59. 384 U.S. 597 (1966); see Comment, The FTC's Power to Seek Preliminary Injunctions in Anti-Merger Cases, 66 MicH. L. Rev. 142 (1967). This system is slightly more fragmented because the Dean Foods case must be seen in conjunction with the reporting requirements authorized by section $6(\mathrm{~b})$ of the Federal Trade Commission 
In any event, reciprocity of duties, leading to the requirenent that the agency clear or file, might well become all filing and no clearing. Because of the chilling effect of the preliminary injunction and the significant, if less chilling, effect of the growing tendency of courts to require completely separate operation of merged business units as a condition of denying an injunction, ${ }^{60}$ it seems that a lesser and lesser amount of enforcement resources, as compared with earlier times, will suffice to carry the antimerger attacks. ${ }^{61}$ If this be so, it might be better for all concerned if the enforcement agencies made their decisions under no more pressure for action than that created by the occasional prodding of interested third parties proposed above.

b. Restrictive distribution practices. There is no easy way to fashion the cquivalent of a notification event from which the chain of inquiry and challenge might spring for restrictive distribution arrangeinents, nor would it be wise to do so in view of the administrative burdens of policing such a concept. The magnitude of the number of transactions that would have to be covered, and the magnitude of the number of review transactions that would thus be imposed upon the enforcement agencies, militate against adoption of such a scheme. It would be hard to devise a better way to render an agency impotent than to drown it in this kind of review duty, as the experience of the Directorate General for Competition of the European Communities tends to demonstrate. ${ }^{62}$

There is far less need for this heavy an approach in the case of such behavioral transactions than in the case of structural changes like mergers. ${ }^{63}$ First, there are already many properly motivated

Act, 15 U.S.C. $\S 46(\mathrm{~b})$ (1964). But see O'Brien, supra note 50, at 561-67, 573-74; Panel Discussion, 39 ANTiTRust L.J. 204, 211 (1970) (comments of Mr. Reycraft).

Each case of seeking a preliminary injunction, according to participating FTC officials, was a "traumatic experience" for the Commission. BNA A.T.R.R. No. 506, at B-3 (1971).

60. See, e.g., United States v. Wachovia Corp., 313 F. Supp. 632 (W.D.N.C. 1970); United States v. Cities Serv. Co., 289 F. Supp. 133 (D. Mass. 1968), appeal dismissed, 410 F.2d 662 (1st Cir. 1969).

Archer, supra note 57, at $190 \mathrm{n} .15$, cites a study finding that 13 of 23 proposed banking nergers were abandoned following the Department's announced intention to object. See also Kestenbaum, Potential Competition, 38 ANTrTrust L.J. 652, 656-57 \& n.15 (1969).

61. See Miller, Technology, Social Change, and the Constitution, 33 GEo. Wash. L. Rev. 17, 28-30 (1964) (query whether he would not now include substantive antitrust law among the fields moved, in this case voluntarily, out of the judiciary's grasp); N.Y. Times, June 29, 1969, at 1, col. 1 .

62. See Buxbaum, Patent Licensing: A Case Study on Antitrust Regulation Within the European Economic Community, 9 ANTrTrust BulL. 101, 143-44 (1964); Buxbaum, Incomplete Federalism: Jurisdiction over Antitrust Matters in the European Economic Community, 52 CaLIF. L. Rev. 56, 58 (1964).

63. See generally Buxbaum, supra note 2, at 358; Posner, A Statistical Study of Antitrust Enforcement, 13 J. LAw \& EcoN. 365, 416 (1970). 
complainants against these transactions, and these complainants have adequate means of redress. The doctrinal shifts in section 3 Clayton Act law, ${ }^{04}$ the new learning as to class actions, ${ }^{65}$ and the demise of the in pari delicto defense ${ }^{60}$ offer those parties with legitimate complaints against restrictive distribution practices sufficient motivation and capabilities to pursue them; therefore, no changes are necessary in the noncomplainant-nonaction situation.

I am persuaded to this view by another factor. In the case of mergers, the financial and political importance of the imdividual event, coupled with the understandable ill ease of the enforcement agencies at social tinkering with a demonstrably efficient machime in order to reach ill-defined and seldom immediately discernible theoretical goals, make antimerger law enforcement a sometime and vulnerable thing, needing as mucl insulation froin short-term political constraints, and encouragement from those with reason to fight, as it can possibly get. An attack upon an exclusive distribution agreement is another matter entirely. Here there is highly visible, alinost tangible behavior, with visible, almost tangible effects upon ascertainable parties or groups; here it is those who argue that there is good in this evil that are the theorists; ${ }^{67}$ and liere the events are seldom important enough, nor the consequences of the government's attack serious enough, to enable significant opposition to mount against governmental enforcement efforts. ${ }^{68}$ In short, the government's total record in the field is fairly good, and where it has lagged behind, others have had little difficulty in picking up the attack. Under these circumstances, a change in procedures for the purpose of energizing now-unmotivated potential coinplainants to scrutinize the government's handiwork, given the attendant enforcement costs that would be involved, seems not only unnecessary but undesirable.

\section{The Proposal Applied to Consent Decree Negotiations at the Departmental Level}

Before leaving this subject of participation in the agencies' decisional process, it may be worthwhile to apply the model established in the preceding discussion to one of the more significant institutional set-

64. 15 U.S.C. $\$ 14$ (1964); see, e.g., Bok, The Tampa Electric Case and the Problem of Exclusive Arrangements Under the Clayton Act, 1961 SUP. Cr. REV. 267.

65. See note 114 infra.

66. See Simpson v. Union Oil Co., 396 U.S. 13 (1969); Perma Life Mufflers, Inc. v. International Parts Corp., 392 U.S. 134 (1968).

67. Compare, e.g., Bowman, Tying Arrangements and the Leverage Problem, 67 YALE L.J. 19 (1957) and Preston, Restrictive Distribution Arrangements, 30 LAW \& CONTEMP. ProB. 506 (1965) with United States v. Arnold, Schwinn \& Co., 388 U.S. 365 (1967) and United States v. Loew's, Inc., 371 U.S. 38 (1962).

68. See generally Buxbaum, supra note 2, at 358. 
timgs in which enforcement possibilities are resolved: the Department of Justice's use of negotiated consent decrees. At least 70 percent of all departmental civil complaints are terminated by consent decree settlement; ${ }^{69}$ in addition, according to a recent incumbent, a few complaints filed are at the moment of filing joined to proposed consent decrees, indicating that occasionally some negotiations leading toward consent settlement are held in the Department before complaint is filed. ${ }^{70}$ These figures indicate the impact that a more open process would have in the entire antitrust enforceinent system. In the past, departmental spokesmen have asserted on the basis of these figures that opening the process to outside participation would reduce seriously the Department's ability to mount the most effective enforcement program with the least resources. ${ }^{71}$ One could alternatively conclude that the figures indicate the importance of a public debate and of reaching a new public consensus about appropriate participation opportunities and procedures. ${ }^{72}$

The participation problem revolves around one point: that at which notice of pending dehiberations or negotiations is given the interested public. The current system is to wait until a proposed consent decree is filed in court and published. Then suggestions and complaints are solicited, addressed to the Department of Justice. ${ }^{73}$ The decision is anticipated, statistically speaking, by the Department's public announcement of the filing of the complaint, but a third party cannot know that any specific complaint will eventually be settled by consent. Further-

69. These figures are for the decade 1950-1959. See Flynn, Consent Decrees in Antitrust Enforcement, 53 IowA L. REv. 983, 986 n.8 (1969). The portion of settled cases of those pursued to some remedy and not dismissed was 87 percent. See id. The figure as of the mid-sixties has been stated to be about 80 percent. See Comment, Consent Decrees and the Private Action, 53 CaLIF. L. REv. 627, 628 n.8 (1965) (reporting comment of then-Assistant Attorney General Orrick). Posner's figure for 1965-1969 is higher: 90 percent. Posner, supra note 63, at 375 (Table 5). See also Note, Closing an Antitrust Loophole, 55 VA. L. REv. 1334, 1337 (1969).

70. Zimmerman, Procedures for Settling with the Antitrust Division, 37 ANTITRUST I.J. 212, 216 (1968). The percentage seems to be rising agaim. See, e.g., Wall St. J., July 10, 1970, at 4, col. 1 (Pac. ed.).

Traditionally the Federal Trade Commission has frequently used the approach of preliminary negotiations and filmg complaints and proposed consent orders. See P. Woll, Administrative LAW-The Informal Process 117-25 (1963). Recently, however, abandonment of this approach was announced, as part of the Commission's rejuvenation. See N.Y. Times, Apr. 10, 1970, at 39, col. 1; Kennedy, Professor Elman and the Changing Federal Trade Commission: A Comment, 59 GEo. L.J. 861 (1971). Thus, the model proposed in the text would not be disruptive of the Commission's working style-unless the recent Goodyear settlement order presages a return to old habits. In re Goodyear Tire \& Rubber Co., 3 TRADE REg. Rep. If 19,522 (March 12, 1971); see II NADER ANTITRUST Study Group, The Closed ENTERPRise System 809 (1971).

71. See Shapiro, supra note 32 , at 743 \& n.104.

72. See, e.g., Votaw, Antitrust in 1914: The Climate of Opinion, 24 ABA SEC. of ANTtrRust L. Proceedings 14, 15 (1964).

73. 28 C.F.R. $\$ 50.1$ (1961). 
more, there is no establisled procedure for channeling criticism at this point in the proceedings, let alone for participation, though the Department voluntarily accepts and considers all information received.

Once the governmental decision to commit resources to an event is made, it would be relatively easy to let that decision be known and allow subsequent participation through procedures such as those previously described. While it would be difficult to shape the government's deliberative processes to accommodate participation before the complaint decision is made, this is fortunately unnecessary except where the decision to sue is kept secret while settlement negotiations proceed and announced at the same time as is the decision to settle. Therefore, if participation im shaping particular settlements is desirable, the only change from present practices needed is to require that no settleinent be formulated until a coinplaint is filed or a proposed complaint is announced. ${ }^{74}$ Any inefficiency that this causes would be relatively insignificant because of the rarity of the particular practice.

Once the use of simultaneous announcements is precluded, thirdparty participation can be implemented to sucli degrees and along such lines as suit the particular transactions. Regulatory-agency procedures provide suitable precedent, ${ }^{75}$ and experience with such peculiarly departmental exigencies as may exist undoubtedly can be met by further refinements.

Above all, what must be avoided is giving an illusion of participation in the decisionmaking processes when in fact agency decisions have already congealed. ${ }^{76}$ Frustration breeds claims of illegitimacy; inordinate effort is required merely to chip at the edges of a set course of action; and if the requisite energies are collected, all-out, all-or-nothing

74. See Zimmerman, supra note 70 , at 216 (indicating the Division's reluctance to utilize the preliminary-negotiations approach).

75. See the excellent example in Freedman, Administrative Procedure and the Control of Foreign Direct Investment, 119 U. PA. L. Rev. 1, 90 (1970). See generally Robinson, The Making of Administrative Policy, 118 U. PA. L. Rev. 485, 515, 519 (1970).

76. See FTC Press Release (May 23, 1969), Separate Statement of Commissioner Ellman:

The public is entitled to know about such an application at the time it is filed, not later .... If there are comments or objections froin interested third parties, we should consider them before we act, not afterwards. . . . [There] is a large difference between the status of a matter which is entirely wide open because the agency has not acted at all, and one in which the door is at least partly closed because the agency has granted "provisional" Id. at 2 . approval.

For an excellent general example, see N.Y. Times, Nov. 13, 1970, at 23, col. 1 (dispute concerning practice of delay in releasing reports under section 102 of the Environmental Policy Act of 1969, 42 U.S.C. $\$ 4332$ (Supp. 1971), which provides that "environmental impact reports" shall be available to the public as the agency review process operates, rather than after the agency decision is made). 
attacks, rather than persuasion to acceptable consensus, become the rule. As a result the total, long-range correctness of decisions is diminished.

\section{III}

\section{Public Participation in Judicial Review of Agency Decisions}

Public participation at the judicial level consists of two things: appeals from agency inaction, and participation in judicial proceedings originally brought by the Department of Justice. Since the outlines of the discussion are clear by now, I shall avoid detailed descriptions of the various modalities of participation, and instead illustrate my proposals by concentrating upon the settleinent (whether by consent decree, dismissal, or after litigation) of actions brought in the courts by the Department. Two aspects of the intervention problem are relevant to this discussion: the showing needed to obtain leave to intervene, and the showing needed to obtain a spectrum of desired results after intervention is allowed.

In pursuing these issues, it is important to keep in mind that there are informal alternatives to Rule $24^{77}$ proceedings. These alternatives are particularly important because intervention is not an all-or-nothing proposition. ${ }^{78}$ Participation in district court consent decree deliberations, for example, is now commonplace, whether or not this participation is formally labeled intervention. ${ }^{79}$ I assume that whatever

77. FED. R. CIv. P. 24.

78. See generally Shapiro, supra note 32 .

79. See Handler, The Shift from Substantive to Procedural Innovations in Antitrust Suits, 71 CoLUM. L. Rev. 1,18 \& $\mathfrak{n} .92$, and sources cited therein. See generally Flynn, supra note 69, at 1005-10; Rotunda, supra note 38, at 202-14; Shapiro, supra note 32 , at $740-48$.

These efforts to obtain third-party participation usually are not successful. See Handler, supra. Some of the failures, however, are substantive decisions in which the court has reviewed the protest against a proposed settlement and on the facts shown decided against it. For example, in United States v. Blue Chip Stanp Co., 272 F. Supp. 432 (C.D. Cal. 1967), aff'd mem. sub nom. Thrifty Shoppers Scrip Co. v. United States, 389 U.S. 580 (1968), the district court not only reviewed the objections, but as the reported opinion itself reveals, twice before had rejected proposed consent decrees after amici curiae had propounded reasoned objections to them in oral argument. Id. at 424. Ironically, the ground unsuccessfully advanced by the putative intervenor against the decree in the third round-fear that Blue Chip Stamp Company, rather than losing market position to newly created competition, wonld extend its inarket domination-has apparently come to pass; at least the Umited States recently moved to open and anend the consent decree on that ground. See Notice of Motion and Motion to Modify the Final Judgment of June 5, 1967, United States v. Blue Chip Stamp Co., Civ. No. 63-1552F (C.D. Cal., filed Oct. 28, 1970). I am advised that the notion was denied with leave to renew.

Another example, of greater public interest, is Urited States v. Harper \& Row Publishers, Inc., 1967 Trade Cas. II 72,256 (N.D. Ill.), aff'd mem. sub nom. City of New York v. United States, 390 U.S. 715 (1968) (the Children's Books case). Here, after putative intervenors' argument, a significant change was made concerning availability of 
the law as to formal Rule 24 intervention, the district courts informally will hear complaints and read letters protesting proposed settlements, so that the real question is what depth of presentation will be allowed. To some extent it is only a tactical question whether, with Professor Shapiro, one argues in favor of formal intervention but concedes the courts' discretion to shape the degree of actual participation to the relevant particular circumstances, ${ }^{80}$ or one is concerned solely with the degree of participation, regardless of the label applied to the third-party participant. All in all, because the formal intervention concept subsumes a minimal guarantee of adequate, though varying, participation rights, ${ }^{81}$ the liberal granting of formal intervention requests is preferable. However, this is not the only possible way to bring about improveinent, for the courts are even now somewhat anenable to informal argument, and they may well become even inore ainenable to such non-Rule 24 third-party participation in the future.

\section{A. The Scope of Intervention}

Despite some disturbing affirmances by the Supreme Court of denials of intervention, ${ }^{82}$ one might begin and end the inquiry into the

the government's evidence. See Archer, The Defendant's View, 37 ANTnTRusr L.J. 837, 846-47 (1968); McSweeney, Privileged Communications, Attorney's Work Product, Confidential Information and Availability of Governmental Investigative Files and Grand Jury Transcripts, 38 ANTITRUsT L.J. 24, $32-33$ (1969). A similar result was rcached in United States v. Automobile Mfrs. Ass'n, 307 F. Supp. 617 (S.D. Cal. 1969), aff'd mem. sub nom. City of New York v. United States, 397 U.S. 248 (1970) (the automobile pollution control case); see 307 F. Supp. at 620 .

Another occasional occurrence is the full participation by objecting third parties in motions to modify consent decrees previously entered, vithout provision for such an occurrence having been made therein. Compare United States v. Western Elec. Co., 1968 Trade Cas. If 72,415 (D.N.J.), aff'd mem. sub nom. Clark Walter \& Sons, Inc. v. United States, 392 U.S. 659 (1968) with United States v. Branch River Wool Combing Co., 320 F. Supp. 1324 (D.R.I. 1971).

Such cases are expectable; the right to participate in the process is no guarantee of victory. Of course, the sufficiency of the fact-finding exercise that led this or that court to reject the protest or proposed change can be questioned. See text accompanying notes $120-26$ infra.

80. Shapiro, supra note 32, at 757-64.

81. One important participation right is that of appeal from a defeat below, a stcp not available to a party enjoying, for example, only amicus curiae status. In this connection, note also the availability to the disappointed putative intervenor of a dircct appeal to the Supreme Court under section 2 of the Expediting Act, 15 U.S.C. $\$ 29$ (1964). See Missouri-Kansas Pipe Line Co. v. United States, 108 F.2d 614 (3d Cir. 1939), cert. denied, 309 U.S. 687 (1940); cf. United States v. California Cooperative Canneries, 279 U.S. 553 (1929).

82. See cases cited in Handler, supra note 79, at 18 n.92. See also United Statcs v. Atlantic Richfield Co., 5 Trade REg. REP. $\int 73,460$ (S.D.N.Y. 1970), aff'd mem. sub nom. Bartlett v. United States, 401 U.S. 986 (1971) (a minor case).

The Supreme Court's use of the straightforward affirmance in these direct appeals rather than dismissal for want of a substantial federal question does not indicate that 
scope of Rule 24 intervention with the El Paso cases, Cascade Natural Gas Corp. v. El Paso Natural Gas Co.$^{83}$ and Utah Public Service Commission v. El Paso Natural Gas Co. ${ }^{84}$ The basic and perhaps unique point of the Cascade holding is that an allegation of disobedience of a higher court's mandate nay be grounds for obtaining formal Rule 24 standing to intervene. ${ }^{85}$ Even though the interests of the intervening complainants in the El Paso cases were no more important or legitimate than those of the custoiners, suppliers, and competitors whose intervention efforts in other cases routinely have been denied, the El Paso complainants were allowed to intervene because they alleged this particular issue. Theoretically, this allegation bears more upon the substantive result a successful intervenor might procure than upon his right to show the error in the first place. Nevertheless, here as elsewhere there is a reciprocal relation between the threshold issue of standing and the issues imvolved in the substantive complaint in intervention. Thus, if the prospective intervenor alleges that he intends to rely upon the agency's deviation from a prior mandate, he is apparently given formal Rule 24 standing to prove his allegation.

The mandate need not be that of the Supreme Court, nor need the issue of disobedience be so starkly put as in El Paso. For example, in United States v. First National Bank \& Trust Co. (Lexington Bank), ${ }^{86}$ a case applying the Cascade holding in the consent decree context, the district court had decided the substantive nonopolization issue against the government, relying erroneously, as it shortly thereafter turned out, ${ }^{87}$ on the supposed effects of the 1966 Bank Merger Act. ${ }^{88}$ Despite the pendency before the Supreme Court of other bank merger cases which might, and later did, result in opposite rulings, ${ }^{89}$ and despite its own prior formal indications to the contrary, the government announced prospective abandonment of its direct appeal and requested entry of a

the general issue of the propriety of allowing intervention, as opposed to the essentially judgmental issue of allowing intervention in a particular case, has been reviewed in any meaningful sense by the Court. See R. Stern \& E. Gressman, Supreme Court PracTICE 197 (4th ed. 1969). In one case the Court dismissed the appeal rather than affirm the judgment, but without invoking the "substantial question" formula. Lupton Mfg. Co. v. United States, 388 U.S. 457, dismissing mem. United States v. Aluminum Co. of America, 41 F.R.D. 342 (E.D. Mo. 1967).

83. 386 U.S. 129 (1967).

84. 395 U.S. 464 (1969).

85. These cases have been analyzed in detail by several writers. See Flynn, supra note 69, at 1005-10; Rotunda, supra note 38, at 202-14; Shapiro, supra note 32, at $740-48$.

86. 280 F. Supp. 260 (E.D. Ky. 1967), aff'd mem. sub nom. Central Bank \& Trust Co. v. United States, 391 U.S. 469 (1968).

87. See note 89 infra and accompanying text.

88. 12 U.S.C. $\$ 1828$ (c) (Snpp. V, 1970).

89. United States v. First City Nat'l Bank, 386 U.S. 361 (1967). The current 
final judgment settling the dispute in favor of defendants. ${ }^{90}$ In permitting intervention in this situation the Lexington court significantly extended the Cascade doctrine. Because the intervenor alleged executive inconsistency which on its face could not be explained by reasoned distinctions between cases or even pro forma policy assertions, it was given a chance to prove the existence of an illegitimate motive.

In fact some of the language of the opinion of the district court suggests even broader intervention rights. The court declared:

If the [Supreme] Court by its decision in Cascade grants intervention of right to any volunteer claiming to speak for the public interest when he can convince a court that the Government might have used bad judgment in conducting or settling a lawsuit, these intervenors are well within the class entitled to intervene..$^{01}$

This statement raises the possibility of intervention in all cases, whether or not the underlying action had been pending before the same or a higher court, so long as it is alleged that the government agency used "bad judgment." Presumably, the bad-judgment allegation need not be based upon a conflict witl judicial pronouncements in the same or related litigation, as was the case in Lexington Bank, but may be demonstrated circumstantially.

The best-known illustration of a case that could have fallen under this broad version of the rule is United States v. Western Electric Co., ${ }^{02}$ involving a challenge to certain patent-pooling practices. The case was ended by a consent decree that not only left prior aetivity unpunished, but more significantly, permitted retention of the fruits of the alleged illegal conduct and failed to correct an ongoing monopoly situation. ${ }^{03}$ There were no prior related judicial pronouncements, and the only proof of the charges alleged against the consent decree was circunistantial: the large disparity between minimal reasonable sanctions and those acceded to by the government. Cases such as this should be within the intervention framework. In order to accomplish this, I would read Cascade to hold that if an allegation of some yet-to-be-analyzed abuse of discretion is made, a complainant who is otherwise entitled to intervene because of his interest in the matter, ${ }^{04}$ ought to be permitted

state of the law is reflected in United States v. Phillipsburg Nat'l Bank \& Trust Co., 399 U.S. 350 (1970).

90. $280 \mathrm{~F}$. Supp. at 263.

91. Id.

92. 1956 Trade Cas. If 68,246 (D.N.J. 1956).

93. See Antitrust SubComm. (SUbComm. No. 5) of the Comm. on the Judictary, 86th Cong., 1st Sess., Report on CONSENT DeCree Program of the DeP'T of Justice 29-120 (Comm. Print 1959). See generally J. Goulden, Monopoly 78103 (1968).

94. Utah Pub. Serv. Comm'n v. El Paso Natural Gas Co., 395 U.S. 464 (1969), does not require even this much. 
to intervene whether the impropriety alleged is a deviation from a situationally related judicial pronouncement or deviation from acceptable law enforcement results. This is no more than the adequacyof-representation ground of the rule, ${ }^{95}$ and the government, above all litigants, should be amenable to an intervention challenge based on these grounds. ${ }^{90}$

It is still unclear what level of wrongful agency action in the settlement process must be alleged to justify intervention and proved to justify rejection of a proposed consent decree. Lexington Bank suggests that a generous level of conclusory pleading-merely alleging "bad judgment"-is acceptable. ${ }^{97}$ A recent case involving the Federal Trade Commission, Robertson v. FTC, ${ }^{98}$ suggests a standard more in keeping with the general concepts of reviewability of discretionary agency action. In that case a dissident warehouseman objected to bylaws adopted by a tobacco marketing board pursuant to an open-ended cease-anddesist order and sought review of the bylaws by the FTC and then by the court. The court held that adoption of the bylaws was part of the general compliance stage of ageney action, so that the hearing procedures required in the adjudicatory stage were not applicable. ${ }^{99}$ However, the court suggested that under section 10(e) of the Administrative Procedure Act ${ }^{100}$ injunctive or declaratory relief would be available if "arbitrary and capricious" action by the FTC - the statutory standardwere alleged. ${ }^{101}$ Since the Department of Justice's activity is best understood if it is considered analogous to the action of an admimistrative agency, the familiar "arbitrary and capricious" wording should, as a pleading, survive a motion to deny the right of intervention, particularly if the less rigorous "bad judgment" standard of Lexington Bank is correct.

It is more difficult to determine what facts need to be proven in order to force an agency to give a fuller justification of its settlement efforts, or if the agency fails to do so, to justify rejection of a proposed consent decree. No precise answer can be given, but some characterization and classification suggestions, buttressed by illustrations from cases, may be of use to decisionmakers confronted with this problem.

At the outset we should recognize that because of the impact that

95. FED. R. Civ. P. 24(b).

96. But see Handler, supra note 79 , at 9, 21-23, 35-36.

97. $280 \mathrm{~F}$. Supp at 263.

98. 415 F.2d 49 (4th Cir. 1969).

99. 415 F.2d at $51-54$.

100. 5 U.S.C. $\$ 706(1970)$ :

.... The reviewing court shall ... (2) hold unlawful and set aside agency action, findings, and conclusions found to be (A) arbitrary, capricious, an abuse of discretion, or otherwise not in accordance with law .... 101. 415 F.2d at 55 . 
intervention in consent decree hearings has on the Justice Department's power to allocate enforcement resources, this must be distimguished from the typical intervention case. In the normal case the litigation continues regardless of the outcome of the intervention attempt. Intervention may reshape the direction of the litigation or the emphasis of particular items, but these are marginal problems. If a consent decree settlement is challenged, however, an overriding consideration is the danger that no settlement will be reached if intervention is allowed and the government forced to litigate. Because of the drain on enforcement resources this causes and because of the initially legitimate presumption that a responsible public agency best knows how to allocate himited resources to protect the public interest, a court must use care in urging or requiting changes in the substance of a proposed decree..$^{102}$

\section{Asphalt-Clause Intervenors}

Where a private party has no quarrel with a settlement except that it deprives him of the benefits of Clayton Act section 5(a) ${ }^{103}$ because it does not include an asphalt clause, ${ }^{104}$ he would bear such a heavy burden of persuasion that rejection of his request to intervene would for practical purposes be mevitable. In only one case might there be an exception to this general rule. If the intervenor represents that class which has suffered froin the competitive restraint being challenged and the class is essentially governmental in nature, ${ }^{105}$ then for several reasons the resource-allocation problem takes on entirely different aspects. First, in this situation the public interest can be equated with that of the intervenor; therefore, the Department of Justice cannot claim that a more general public is being shortchanged if the consent decree founders due to insistence upon an asphalt clause. ${ }^{106}$ Second,

102. To this extent, and subject to recognition of the fact that the question of degree, not kind, is the difficult one, I can subscribe to the concerns so stridently voiced in Handler, supra note 79 , at 17-23.

103. 15 U.S.C. $\$ 16$ (a) (1964).

104. See note 34 supra and accoinpanying text.

105. See, e.g., United States v. Harper \& Row Publishers, Inc., 1967 Trade Cas. II 72,256 (N.D. Ill. 1967), affd mem. sub nom. City of New York v. United States, 390 U.S. 715 (1968). I assume that the class action device brings the entire public-body group into the intervention complaint.

I do not include here the debated parens patriae actions of the state, the legitimacy of which will be determined by the Supreme Court in Hawaii v. Standard Oil Co., 431 F.2d 1282 (9th Cir. 1970), cert. granted, 401 U.S. 936 (1971), or stato agency efforts to intervene in other state-agency cases. See, e.g., City and County of San Francisco v. Chas. Pfizer \& Co., 48 F.R.D. 105 (S.D.N.Y. 1969).

106. Even if defendants would find asphalt clauses for the benefit of public victims equally objectionable whether the beneficiaries exhausted the list of affected parties or were only a part thereof, the government's resource-allocation objection is least tcnable in the former case.

Of course the anticompetitive effects of a violation may emanate beyond the first 
any departmental arguinent that by losing the benefits of the proposed decree the intervenor is hurting himself or his class is entitled to little weight. Those who seek to intervene obviously disagree with that assessment; their governmental status slould assign to their dissenting opinion the same weight as that given the Department of Justice's opinion. Third, the tax dollars that will pay for the intervenor's later private action are no less sacrosanct than the tax dollars supporting the work force of the Antitrust Division; therefore, any argument by the Department of Justice that intervention requests should be denied in order to save enforcement resources niust be rejected. I realize that the laboring oar in these governmental actions is often taken by private attorneys on a contingent fee basis ${ }^{107}$-indeed, the entire local government treble-damage effort is hardly feasible without this contingent fee-engendered self-interest-but the eventual recoupment is nevertheless a tax substitute for public expenditure. Furthermore, the Department's resource-allocation difficulties can be mitigated through the expedient of allowing the local agencies' attorneys to enter the original departmental lawsuit, which then can proceed as an action for both injunctive and monetary relief. ${ }^{108}$ The Department of Justice staff would supervise the agencies' attorneys, but the latter, acting as special counsel for the government, would bring the origmal case to judgment. Then, either at once or after appellate finality, the agencies' counsel could proceed with the treble-damage aspect of the case, using the prima facie benefit of Clayton Act section 5(a).

\section{Intervenors Seeking Affirmative Relief}

The more significant objections to the settlement of pending de-

circle of victims to affect the economy more generally, but this does not strike me as a reason to reject the proposed approach, given the existing limitations on recovery by remotely injured and indirectly harmed parties. See Billy Baxter, Inc., v. Coca-Cola Co., 431 F.2d 183 (2d Cir. 1970), cert. denied, 401 U.S. 923 (1971); Karseal Corp. v. Richfield Oil Corp., 221 F.2d 358 (9th Cir. 1955).

107. See, e.g., CAL. BOS. \& PROF. CODE $\$ 16750$ (West 1964) (allowing the Attorney General to enter into agreements with persons to prosecute antitrust actions brought on behalf of the state or an agency thereof; presumably it includes the power to conclude contingent fee arrangements). See generally Blecher, An Effective Deterrent to "Hard Core" Violations of the Antitrust Law, 14 U.C.L.A.L. REv. 1060 (1967).

108. Technically the two cases could be tied together through either a joinder of parties pursuant to Rule 20 (a) or through intervention. While I have found no case in which the parties joined as plaintiff were governmental and private, there is no reason to bar such voluntary jomders. And, as the Children's Books litigation [United States v. Harper \& Row Publishers, Inc., 1968 Trade Cas. II 72,415 (N.D. III. 1967), aff'd mem. sub. nom. City of New York v. United States, 390 U.S. 715 (1968)] shows, state and local public bodies have joined in intervention efforts which, if successful, would have resulted in a joinder of public and private bodies. Regardless of whether joinder or.intervention is employed, the district court's approval is required, but this approval should be given if the United States, the plaintiff, concurs in the application. 
partmental litigation come from those third parties who seek the inclusion of some form of affirmative rehef in the settlement decree. The most useful classification for such objections is one based upon the distinction between a decree imposing a sanction upon past behavior and one compelling a change of structure or behavior in the future. It is tempting to think instead in terms of a structure-behavior dichotomy, but as demonstrated below, ${ }^{109}$ that dichotomy offers only a loose and not always useful correlation to the more meaningful distinction suggested.

The types of intervention rights appropriate to the different types of third parties I distmguish can be sketched by considering a hypothetical case of each. In the first case, a government action is brought to end an illegal pricing conspiracy. The government proposes a consent decree forbidding the continuation of the conspiracy and fining the conspirators; in the opinion of the Department of Justice, this will adequately assure future good behavior. In the second case, after filing an antimerger complaint, the government seeks a consent decree forbidding only future mergers but continuing undisturbed a situation alleged in the complaint of that very suit to be illegal. The proposed government action in the first case achieves the major goal, ending the illegal situation. Therefore, competitors, customers, and others affected by the prior illegal behavior should not be able to challenge the action merely because it supplies no public redress for past illegal acts. In the second case, however, third parties otherwise enjoying good standing ought sometimes to be able to intervene and complain that the Department has failed to protect them from the continuing harm. The dubious argument asserted by the Department of Justice in these cases to support its settlement decrees-that resource allocation and enforcennent priorities override acceptance of a continuing, illegal, harmful structureshould not foreclose further judicial inquiry. ${ }^{110}$ The government inay still argue a type of confession and avoidance to this charge of surrender. Therefore, a proper judicial decision whether to accept the decree or not should also consider such matters as the certainty of the legal issue al-

109. See text accompanying notes 115,116 infra.

110. See, e.g., the public debate over the Department of Justice's resolution of the Ling-Temco-Vought case involving the Jones-Laughlin transaction, Wall St. J., Mar. 28, 1969, at 4, col. 1 (Pac. ed.); Wall St. J., Mar. 9, 1970, at 26, col. 1 (Pac. ed.), and the LTV case involving the Okonite transaction, United States v. Ling-Tenico-Vought, Inc., 5 Trade Reg. ReP. $\lceil 73,607$ (W.D. Pa. May 27, 1971). The FTC has also consented to decrees of this type. See, e.g., Diamond Crystal Salt Co., [1967-1970 Transfer Binder] Trade Reg. Rep. IT 19,027 (1969); Litton Indus., Inc., [1967-1970 Transfer Binder] Trade Reg. Rep. đI 18,828 (1969); Marquette Cement Mfg. Co., [1967-1970 Transfer Binder] TRADE REG. REP. đ 18,888 (1969); Burlington Indus., Inc., [19671970 Transfer Binder] Trade REg. Rep. II 18,589, đT 18,635 (1969); Occidental Petroleum Corp., [1967-1970 Tṛansfer Binder] Trade REg. ReP. ITा 18,527, 18,599 (1968). See also cases cited in Burrus \& Mayne, Developments in Antitrust During the Past Year, 39 ANTITRUST L.J. 533, 621-22 (1970). 
leged to govern; $;^{111}$ the closeness of private complainants and their harm to the effects of the continuing, illegal situation;:112 the availability of direct private action, as under section 7 of the Clayton Act; ${ }^{113}$ and the potential use of class actions as alternatives to these intervention efforts. ${ }^{114}$ Generally, however, courts ought to be reasonably accessible to a third party complaining about a proposed settlement because he is the victim of uncorrected, ongoing illegality.

As these examples suggest, the basic classification corresponds to some degree to a simple structure-behavior dichotomy. There is, however, a major third category of problems which does not fit within this traditional distinction. Often the future effects of past behavior remain to do harm though the behavior is ended.115 For exanple, complainmg third parties might show that continuing harn will result because a defendant, though ordered to stop receiving exclusive grantback rights from licensees, will continue to hold an illegitimately derived dominance in the market-a dommance that, through continued attraction of future ideas, will be maintained, if not strengthened.116 Here, too, it is reasonable to adopt a relatively open position toward allowimg intervention if an appropriate level of arbitrarmess in the decision to settle is alleged.

This may be slightly inconsistent with the proposal regarding

111. See, e.g., United States v. Pan Am. World Airways, Inc., 193 F. Supp. 18 (S.D.N.Y. 1961), rev'd, 371 U.S. 296 (1963), where the governnient, forced to litigate by the district court's rejection of a proposed consent decree, lost in the Suprenie Court on primary jurisdiction grounds. However, one cannot tell whether this legal issue was the reason for the settlement effort.

112. E.g., compare Billy Baxter, Inc. v. Coca-Cola Co., 431 F.2d 183 (2d Cir. 1970), cert. denied, 401 U.S. 923 (1971) with Mulvey v. Samuel Goldwyn Productions, 433 F.2d 1073 (9th Cir. 1970), cert. denied, 402 U.S. 923 (1971).

113. 15 U.S.C. $\$ 26$ (1964). Allowing more intervention in merger settlements would be consonant with the emerging position of the federal courts toward private antimerger actions. For example, if a private litigant requests that a court order divestiture to prevent sonie feared prospective injury, the courts would hesitate to give him this private-attomey-general status in a case like this because it involves major structural shifts. This type of litigant is therefore preferred in the schenie proposed in the text. On the other hand, the treble-damage claimant asserting harm from past inergers is less favored by that scheme, but he is more favored by the courts when litigating in his own right. Compare Gottesman v. General Motors Corp., 414 F.2d 956 (2d Cir. 1969) with Highland Supply Corp. v. Reynolds Metals Corp., 327 F.2d 725 (8th Cir. 1964). See generally Day, Private Actions Under Section 7 of the Clayton Act, 29 ABA SEC. OF ANTTTRUST LAW Procendings 155 (1965).

114. See generally Fine, Class Actions, 38 ANTrTrust L.J. 710 (1969). For a discussion of the solicitation problem see Eisen v. Carhisle \& Jacquelin, 52 F.R.D. 253 (S.D.N.Y. 1971); Ward \& Elliott, The Contents and Mechanics of Rule 23 Notice, 10 B.C. IND. \& CoM. L. Rev. 557 (1969).

115. See United States v. United Shoe Mach. Corp., 110 F. Supp. 295 (D. Mass. 1953), aff'd mein., 347 U.S. 521 (1954).

116. See, e.g., United States v. General Elec. Co., 82 F. Supp. 753 (D.N.J. 1949); United States v. General Elec. Co., 115 F. Supp. 835 (D.N.J. 1953). 
asphalt-clause intervenors ${ }^{117}$ in that, logically, a party's inability to bring an "easy" treble-damage action for past harm differs only in degree froin disabilities arising from failure to correct an ongoing economic unfairness, for a failure to make a damaged participant whole impairs his effective participation in economic life, even in the future. Nevertheless, the difference of treatment suggested above is appropriate. It is expedient to avoid automatic complaints agamst departmental action, and because the ordinary treble-daunage complainant is already well armed for his efforts to bring such a private action, lie need not be given the additional aid of the asplialt clause merely to improve further his cliances to achieve that end. Today's liberal use of the class action device, judicial approval of - and even participation in-client solicitation in these cases, ${ }^{118}$ the availability of government files to the private plaintiff, ${ }^{110}$ and the constant erosion of procedural obstacles to private actions all reduce the seriousness of complaints against departmental willingness to settle without preserving the benefits of section 5(a) for private trebledamage actions. These factors justify ignoring this minor logical inconsistency in the past-future categorization.

\section{B. Appropriate Intervention Procedures ${ }^{120}$}

At present the procedures utilized by courts to determine the riglts

117. See text accompanying notes 103-08 supra.

118. See, e.g., Eisen v. Carlisle \& Jacquelin, 52 F.R.D. 523 (S.D.N.Y. 1971). Handler's strictures against this phenomenon [see Handler, supra note 79, at 7-10] are not convincing. The notice mechanics as often as not work to knock out of the recovery arena-permanently, given the statute of limitations-those absent class members who fail to respond to the court's demand that they present their damage claims. See, e.g., Neuman v. Electronic Specialty Co., [1969-1970 Transfer Binder] Fed. Sec. L. Rep. \ 92,591 (N.D. Ill. 1969); Comment, 38 U. CFI. L. REv. 337, 353-55 \& n.91 (1971). See generally Korn v. Franchard Corp., 50 F.R.D. 57, 59-60 (S.D.N.Y. 1970). The problem is to be distinguished from the tolling effects on absent members of the class action brought; see State of Minnesota v. United States Steel Corp., 44 F.R.D. 559, 572 (D. Minn. 1968).

119. United States v. Harper \& Row Publishers, Inc., 1967 Trade Cas. $\llbracket 72,256$ (N.D. Ill. 1967), affd mem. sub nom. City of New York v. United States, 390 U.S. 715 (1968). For a discussion of prior criminal actions and discovery after "no contest" pleas, see Freeman, The Private Plaintiff's View, 38 ANTITRust L. REv. 827 (1968); Kramer, Subsequent Use of the Record and Proceedings in a Criminal Case, 38 ANT1TRUST L. REv. 300 (1969) (a brief overview); McSweeny, supra note 79, at 31. For an interesting imformal alternative, see Washington v. American Pipe \& Constr. Co., 41 F.R.D. 59 (S.D. Cal. 1966). See generally Minnesota Mining \& Mfg. Co. v. New Jersey Wood Finishing Co., 381 U.S. 311,319 (1965).

The only difficult problem is the discovery of CID-derived information when the government either decides not to proceed at all or settles with a consent decree. Even here, however, the retained copies in the government's files should be available. See Decker, The Civil Investigative Demand, 20 ABA Sec. ANtitrust L. Proceedinos 370, 381-82 \& n.58 (1962). But see 28 C.F.R. \& 16.12 (Supp. 1971) (prior approval of the Attorney General required even in the case of court-ordered disclosures). In any event, the private plaintiff can seek discovery from the defendant of the itenis that the defendant subinitted earlier to the Department in response to a CDD.

120. I leave out of consideration the fact-finding possibilities inlerent in the De- 
of parties seeking to intervene in consent decree settlement hearings are. inadequate. The formal intervention motion is often debated in a framework seemingly derived froin motions for summary judginent, with affidavits and briefs substituting for substantive debate about the disparity between the minimum acceptable relief and that sought in the proposed settlement decree. ${ }^{121}$ Initially the negotiated plea is presented to the court with only so mucl explanation and argument as the conscience of that court may require the parties to supply. The government's objection to a proposed intervention is usually limited to pious conclusions reiterating the resource-allocation dilemma and the presumption of legitimacy attaching to decisions of duly appointed representatives of the public. ${ }^{122}$ These are hardly the rejoinders from which the necessary information can be derived to determine the inadequacies of the proposed consent decree or the legitimacy of the would-be intervenor's standing to object. The court should require that the government's rebuttal discuss the issue of alleged inadequate relief in appropriate detail, explaining and justifying its failure to ask for the kind of relief that the challenger suggests would be appropriate.

The following example illustrates the shortcomings in the present procedures. In a recent case, cominenting on an "offer of proof" affidavit submitted by a putative intervenor under a two-day deadline imposed by the court, the judge concluded:

[T]n this case the record was so sparse at argument on the motion as to require further illumination. It appeared to be, and has proved, advisable, in the public interest, to have allowed Nederlander to submit its offer of proof but [because Nederlander's estimate of the situation is based on hypothesized violations in the future] I find the present state of the record to be adequate and complete and that no further proceedings are required. ${ }^{123}$

The third-party complainant alleged in its affidavit that the proposed theater purchases, legitimate under the settlement put forward by the government, would probably foreclose competing theater exhibitors' opportunities, an allegation of the type that should have required response

partment of Justice's own third-party complaint procedure [see text accompanying note 73 supra] whereby notice of proposed consent decrees is published, and objectors are invited to comment, but only to the Department. The Department has at least once invited third parties to communicate directly with the court as amici curiae, but I believe this was done in an effort to build a record favorable to the proposed settlement. United States v. Shubert, 1969 Trade Cas. $\pi$ 72,859 (S.D.N.Y. 1969).

121. See, e.g. Stadin v. Union Elec. Co., 309 F.2d 912 (8th Cir. 1962), cert. denied, 373 U.S. 915 (1963).

122. See Antrtrust Subcomm. (SUbcomm. No. 5) of the House Comm. on the Judiciary, 86TH CONG., 1sT SEss., supra note 93; Buxbaum, supra note 2, at 368; Rotunda, supra note 38 , at 225.

123. United States v. Shubert, 1969 Trade Cas. $\pi 72,859$, at 87,228 (S.D.N.Y. 1969). 
from the government on that substantive issue. Resource-allocation arguments, if justifyingly presented, might be dispositive in such a case, but they can hardly be so until the court has at least considered the legitimacy of the putative intervenor's objection and the distance between its proposed result and that of the proposed decree. In order to fulfill such a function, a court may well have to receive such information as rudimentary market description and classification data-perhaps through written documentation and counterdocumentation. ${ }^{124}$ The point is that the process can be informal and flexible, but serious consideration must be given to the specific objections.

I do not wish to minimize the braking effect that more generous mitial fact-finding procedures may have on the disposition of governmental antitrust actions. Efficiency of disposition is disfunctionally linked with reasonable openness toward third-party intervention and participation. While a small, incremental change in a proposed decree may require only minimally greater resource expenditure, and may be acceptable to a defendant within the same interest-analysis framework that led to its decision to settle with the government in the first place, a major expansion of a decree may not only be expensive in terms of agency time and effort in making the changes, but may scuttle the chance of consensual settlement itself. Yet there is little correlation between importance of the antitrust case and the ease of its resolution along this axis. A consent decree terminating an antimerger challenge by allowing the defendant to keep some of the merged entitics, for example, might not survive objection by a third party, yet to reject the third-party participation on that ground is to vitiate the whole concept of public participation in discretionary decisional processes. The dilemma cannot be resolved except in the sense that courts ought to strike balances in this field generous to serious allegations, and perimitting at least initial proof-procedures; the large decision to allow the unfolding of a full-blown fact-finding and law-arguing process can then be made through stage-by-stage decisions as they may become necessary. That the fear of the delay that might result from this accommodation justifies care in defining abuse of discretion goes without saying; but that fear is a factor in the balance of the judgment, not a preliminary ground for turning away justified challenges.

124. More common and less time-consuming, but also less satisfactory, is the practice of allowing variously denominated third parties (amici curiae, putative intervenors, objectors, etc.) to participate in a general and free-wheeling oral argument at which issues of standing and substantive grounds of objection are mixed together. See, e.g., United States v. Ling-Temco-Vought, Inc., 315 F. Supp. 1301 (W.D. Pa. 1970) (although in this case the court as a result of the hearing was able to identify and calendar for fuller discussion several issues left untouched by the original parties, if done to satisfy a vague feeling that a "hearing" be given by the district court to all invitees and trespassers, then at least formal offers of proof, hearing briefs, and the like should be permitted and responses to them required). 
The formal requisites of discretionary intervention set forth in Rule $24^{125}$ are not inconsistent with this approach once we recognize that to some extent both the lawsuit and the intervention thrust in consent decree hitigation are outside the ordinary frame of reference postulated by the structure of Rule 24 . Certainly the twin grounds governing discretionary intervention under the rule, adequacy of representation and undue delay, are not at issue here as they are in the normal case. Representation is a central issue, but inadequacy of representation is subsumed within the charge of abuse of discretion inferred by the intervenor from the alleged disparity between the proper rehef and that contamed in the proposed decree. Delay in the disposition of the litigation is also involved, but agam not in the traditional sense. The amount of delay involved in undertaking efforts, eventually either successful or abandoned, to improve the terms of the proposed decree ought to be acceptable. The more important delay is that involved when the court is moved to accept the intervenor's charges, reject the decree, and force the Department to consider full litigation of the original complaint. Such delay, however, is not grounds for rejection of intervention under the rule; rather, it is the price which the court must find acceptable before the intervenor can be successful on the merits.

Another factor distinguishes antitrust from other litigation and justifies this emphasis on openness and flexibility in the treatment of would-be intervenors. Usually intervention is accepted because in the opinion of the tribunal the intervenor's pursuit of his personal interest is compatible with-or at least is not detrimental to-the resolution of the dispute as originally framed by the parties; the assistance of the intervening party to the tribunal in achieving a proper resolution of the matter is a secondary and umecessary benefit. In the intervention model I lave sketched for antitrust litigation, lowever, the aims of the intervening party are secondary and not themselves a reason for permitting intervention. The primary purpose and justification of intervention in this field is the public benefit: the improvement of antitrust enforcement achieved by forcing the proposed consent decree through the screen of adversary argument. ${ }^{126}$ Special efforts to accommodate public participation, even in this nontraditional field of administrative law, are therefore warranted.

\section{CONCLUSION}

Enforcement of the antitrust laws has become an administrative

125. Fed. R. Crv. P. 24.

126. Compare the implied tort doctrine, with its increasing concern for use of the private action to assist in the implementation of certain public policies. See, e.g., Baird v. Franklin, 141 F.2d 238, 245 (2d Cir.), cert. denied, 323 U.S. 737 (1944); Astor v. Texas Gulf Sulphur Co., 306 F. Supp. 1333, 1340 (S.D.N.Y. 1969). 
function, and as such should be subject to those participation and review processes which are used in analogous agency situations. An appropriate though rudimentary sketch of an appropriate participation process has been attempted in this Article; as is the case with any such model the specifics are only preliminary suggestions that should be subjected to debate and refinement. The underlying theme, however, ought by now to be accepted: the argument that the agency's function will be inhibited and rendered less efficient by control is no more acceptable in the context of antitrust enforcement than it is in any other administrative context. We do not accept the argument as an a priori justification for avoidance of public scrutiny when television licenses are issued, when subsidies are administered, when truck routes are issued or withdrawn, or when roads are permitted or forbidden to run through national forests; we should not accept the assertion here either. 